\title{
Brazilian Academy of Cardiovascular Surgery: From Idea to Reality
}

\author{
José Wanderley Neto ${ }^{1,2}$, MD, PhD; Enio Buffolo ${ }^{3}, \mathrm{MD}, \mathrm{PhD}$; José Teles de Mendonça ${ }^{4}$, MD, PhD
}

DOI: 10.21470/1678-9741-1-2020-0631

\section{"Knowledge is the paradox in which dividing is multiplying."}

During the Heart Transplantation Symposium in Maceió, in October 2019, the idea of creating the Brazilian Academy of Cardiovascular Surgery was born and aimed at documenting, for future generations of cardiac surgeons, the rich history of cardiac surgery in Brazil.

First-generation Brazilian cardiac surgeons were not just spectators ${ }^{[1]}$, but participants in the development of surgical procedures in the treatment of coronary artery disease ${ }^{[2,3]}$, heart failure ${ }^{[4,5]}$, valvular heart surgery ${ }^{[6,7]}$, congenital heart surgery ${ }^{[8-10]}$ and many others ${ }^{[11,12]}$. In addition, they developed expertise in the manufacture of medical equipment in Brazil, such as heart lung machine ${ }^{[13,14]}$, oxygenators ${ }^{[15,16]}$, pacemakers ${ }^{[17]}$, valves ${ }^{[18-20]}$, stents ${ }^{[21]}$ and many others ${ }^{[1]}$. This allowed to overcome the difficult trade barrier for materials and equipment necessary for the development of the specialty at that time, easing costs of procedures and enabling the application of techniques and concepts from developed countries. Surgical equipment and supplies manufactured in Brazil were soon recognized for their excellent quality. They were subsequently exported and used in many countries in Latin America and other continents, contributing to the development of cardiac surgery in these countries and helping to save lives ${ }^{[22]}$.

When one reads articles such as "Cardiovascular Surgery in Brazil: Achievements and possibilities", written by Euryclides de J. Zerbini, about a symposium held in 1963, with the participation os Dr. Zerbini and Antonio C. de Azevedo, Cid Nogueira, Domingo J. de Moraes, Hugo J. Felipozzi, Delmond Bittencourt, Adib D. Jatene and Jesse Teixeira ${ }^{[1]}$,"History of World Cardiac Surgery"by Domingo Braile and Moacyr Godoy ${ }^{[23]}$, "Short History of Cardiac Surgery:

'Ex-Presidente da Sociedade Brasileira de Cirurgia Cardiovascular Brasileira (SBCCV), São Paulo, SP, Brazil.

2Diretor do Instituto de Doenças do Coração de Alagoas (IDC), Maceió, AL, Brazil. 3Prof. Titular da Discipline of Cardiovascular Surgery, Hospital São Paulo, Escola Paulista de Medicina, Universidade Federal de São Paulo - EPM-UNIFESP, São Paulo, SP, Brazil.

${ }^{4}$ Cardiovascular Surgery Division, Universidade Federal de Sergipe (UFS), Aracaju, SE, Brazil. and everything happened before our eyes" by Paulo Prates ${ }^{[24]}$ and "History of Brazilian Cardiac Surgery" by Iseu Affonso da Costa ${ }^{[25],}$ one can witness the development of what is now considered one of the most beautiful, recent and complex medical specialties: cardiovascular surgery.

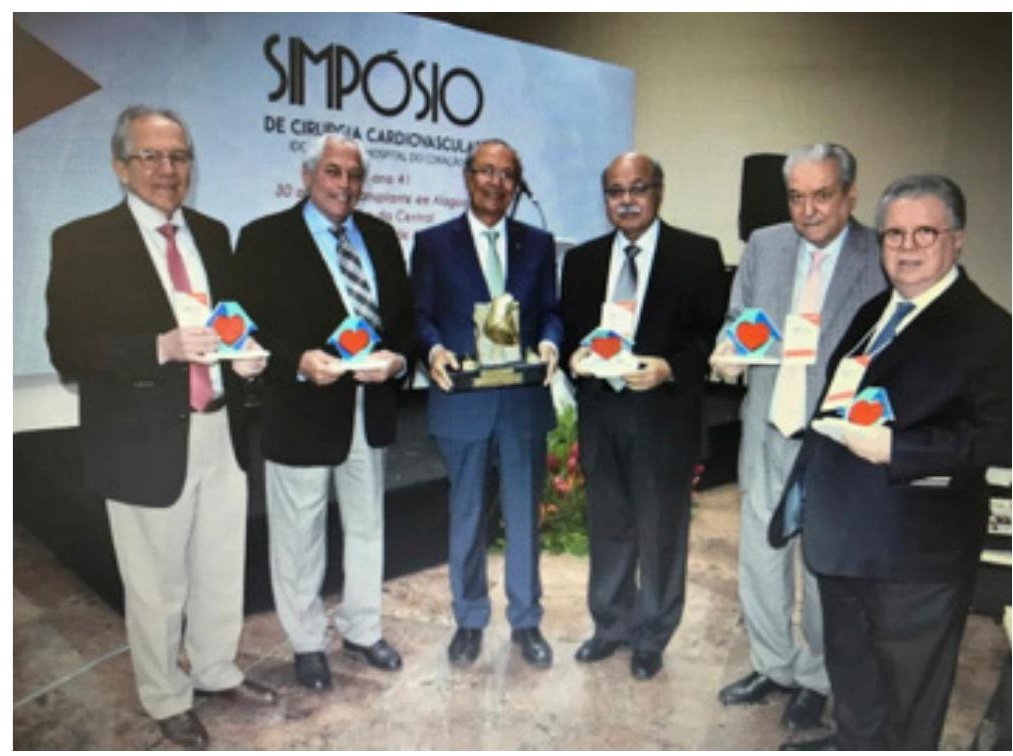

Ricardo Lima, Mozart Escobar, José Wanderley Neto, José Teles, Enio Buffolo and Fernando Lucchese, Foundation of the Brazilian Academy of Cardiovascular Surgery, Maceió, Brazil, 2019.

Correspondence Address:

Enio Buffolo

(iD) https://orcid.org/0000-0001-8715-6400

E-mail:enio.buffolo@terra.com.br 
The courage and determination of cardiologists and cardiac surgeons in Brazil were the same as in the more developed countries. This resulted in the development and application of technology and procedures with minimal delay in Brazil[26]. Great enthusiasm and momentum at the time further enhanced their creativity, contributing greatly to technical innovations in the world of cardiac surgery ${ }^{[19]}$.

These masters also emphasized that medicine is the most wonderful and enriching of all professions, and that it is complete when practiced with passion. It must also be practiced with continuous and inexhaustible affection, solidarity, empathy and compassion ${ }^{[27]}$.

Traditionally, an academy differs from association, society or syndicate. The academy is aimed at preservation of history, science, legacy for young surgeons, and does not represent any government or opposition. The academy emphasizes knowledge and human beings, participating in the teaching of medicine at different stages of a surgeons' career. It also constitutes, in a particular way, the universality of science ${ }^{[28]}$.

One of the pre-requisites to become a member of the Brazilian Academy of Cardiovascular Surgery is to have at least 30 years of clinical practice. This allows for contribution to the development and teaching in a specialty that has had glorious but also challenging and difficult moments. This knowledge and experience will then be transmitted to in-training cardiac surgeons, through meetings, in which invitees can present historical perspectives from professors. There will also be sessions aimed at recognizing those who contributed to the development of our specialty. Occasionally, there will be opportunities to hold sessions aimed at the general population, presented by special guests.

The basic foundation of the Brazilian Academy of Cardiovascular Surgery is original, because it is aimed at cultural differentiation of a specialty, and does not have the format of the National Academy of Medicine, or State Academies, from Brazil, which brings together all other medical specialties.

The rescue of history is also fundamental for medicine, as stated by Emile Paul Littre: "if medical science is not to be lowered to office level, consideration should be given to its history and old monuments from the past"[29].

The Academy will not compete or occupy the space naturally dedicated to the Brazilian Society of Cardiovascular Surgery and will have no political intentions. The objective of the Academy is to complement medical knowledge through cultural exchange. This will be the goal of the Brazilian Academy of Cardiovascular Surgery, honoring our dear friend, Domingo Marcolino Braile, who represented the ethos of the Brazilian Academy, and should have been its first president.

"The supreme science is history, because it is the only work built by men." (Giambattista Vico, Principi de una Scienza Nuova, 1725)[29].

Signed by 5 former presidents of the SBCCV*, 3 full members ${ }^{* *}$, 1 past president in memoriam ${ }^{* * *}$, and 3 international honorary members ${ }^{* * *}$

Domingo Marcolino Braile *** $^{*}$

Enio Buffolo*

Fabio Biscegli Jatene*

Fernando Antonio Lucchese ${ }^{* *}$

José Wanderley Neto*

José Teles de Mendonça*

Manuel de Jesus Antunes****

Mozart Augusto Soares de Escobar**

Paulo Roberto Slud Brofman*

Ricardo de Carvalho Lima**

Rodolfo A. Neirotti****

Tomas Antonio Salerno****

\section{REFERENCES}

1. Zerbini E de J. Cardiovascular surgery in Brazil: achievements and opportunities. Rev Bras Cir Cardiovasc. 2010;25(2):264-77. doi: 10.1590/ s0102-76382010000200024.

2. Buffolo E, Summo H, Aguiar LF, Teles CA, Branco JN. Myocardial revascularization in patients 70 Years of age and older without the use of extracorporeal circulation. Am J Geriatr Cardiol. 1997;6(1):7-15.

3. de Carvalho Lima R, de Escobar MA, Diniz R, de Alencar França NA, et al. How much myocardial revascularization can we do without extracorporeal circulation? Heart Surg Forum. 2002;5(2):163-7.

4. Jatene AD. Left ventricular aneurysmectomy. Resection or reconstruction. J Thorac Cardiovasc Surg. 1985;89(3):321-31.

5. Batista RJ, Verde J, Nery P, Bocchino L, Takeshita N, Bhayana JN, et al. Partial left ventriculectomy to treat end-stage heart disease. Ann Thorac Surg. 1997;64(3):634-8. doi: 10.1016/s0003-4975(97)00779-0.

6. Zerbini EJ, Curti P, Prata L, Felipozzi H, Margutti R, Galucci C. Tratamento cirúrgico das lesões da válvula mitral em 208 casos. Rev Assoc Med Bras. 1957;3(1):25-32.

7. Puig LB, Verginelli G, Belotti G, Kawabe L, Frack CC, Pileggi F, et al.

Homologous dura mater cardiac valve. Preliminary study of 30 cases. J Thorac Cardiovasc Surg. 1972;64(1):154-60.

8. Zerbini EJ. The surgical treatment of the complex of Fallot: late results. J Thorac Cardiovasc Surg. 1969;58(2):158-77.

9. Jatene AD, Fontes VF, Paulista PP, de Souza LC, Neger F, Galantier M, et al. Successful anatomic correction of transposition of the great vessels. A preliminary report. Arq Bras Cardiol. 1975;28(4):461-64.

10. De Mendonça JT, Carvalho MR, da Costa RK, Franco Filho E, Costa GB. Aorto-subclavioplastia com preservação do fluxo arterial: padronização técnica. Rev Bras Cir Cardiovasc. 1993;8(2):63-82.

11. de Moraes DJ, de Moraes MCJ, Dias JR, Martins P, Moraes ZCJ, de Souza $C G$, et al. Uso de oxigênio puro e shunt veno-arterial nos oxigenadores de membrana. Rev Bras Cir Cardiovasc. 1997;12(1):77-82. doi:10.1590/ S0102-76381997000100013.

12. Kormann, DS, Pachón Mateos, JC, Albornoz, RN, Medeiros RC, Kormann SJ, Gizzi JC, et al. Estimulação cardíaca com tele-anodo: uma nova técnica para estimulação elétrica do coração. Rev Bras Cir Cardiovasc. 1986;1(1):1-13. 
13. Felipozzi HJ, Santos RG, D'Oliveira LG, Perfeito JS. Cirurgia cardíaca a céu aberto com desvio extracorpóreo da circulação do coração direito. Resultados experimentais e primeiros casos clínicos. São Paulo: Departamento de Cirurgia; Associação Paulista de Medicina. 16 Nov 1955.

14. Gomes WJ, Saba JC, Buffolo E. 50 years of cardiopulmonary bypass in Brazil: Hugo J. Felipozzi, the pioneer of cardiopulmonary bypass in Brazil. Braz J Cardiovasc Surg. 2005;20(4):III-VIII. doi:10.1590/S010276382005000400002.

15. Drummond M, Braile DM, Lima-Oliveira AP, Camim AS, Oyama RSK, Sandoval GH. Technological development of membrane oxygenators. Braz J Cardiovasc Surg 2005; 20(4): 432-7.

16. Cunha MA, Santos GS, Moraes DJ, Feitosa LA, Abilio FM, Aragão E, et al. [The Brazilian disposable bubble oxygenator. 5000 operations with the DMG model]. Arq Bras Cardiol. 1980 Oct;35(4):283-6. Portuguese.

17. Melo CS, Cardinalli Neto O, Silva LM. Aquilina O, Lourenço AD, Silva Junior O. A fantástica história da eletroterapia, eletrocardiografia e estimulação cardíaca artificial. In: Melo CS, Mateos JCP, Gonçalves JGF, Grego OR, Silva Junior O. Temas de marcapasso. 4.ed. São Paulo: Leitura Médica; 2011. p. 43-114.

18. Braile D. Prótese valvular de pericárdio bovino desenvolvimento e aplicação clínica em posição mitral [thesis]. São Paulo: Escola Paulista de Medicina, Universidade Federal de São Paulo; 1990. 110 p.

19. Vrandecic MO, Gontijo Filho B, Paula e Silva JA, Fantini FA, Barbosa JT, São Jose MC, et al. Estudo multicêntrico dos resultados das trocas valvares com o uso da bioprótese Biocar no Estado de Minas Gerais. Rev Bras Cir Cardiovasc. 1988;3(3): 159-68.

20. Gaia DF, Palma JH, Ferreira CBND, Souza JAM, Gimenes MV, Macedo
MT, et al. Transcatheter aortic valve implantation: results of the current development and implantation of a new Brazilian prosthesis. Braz J Cardiovasc Surg. 2011;26(3):338-47. doi:10.5935/1678-9741.20110007

21. Palma da Fonseca JH, Buffolo E, Carvalho AC, Geisthovel N, Rodrigues Almeida D, de Souza JAM, et al. Utilização de endoprótese autoexpansível (Stent) introduzida através da artéria femoral para tratamento de dissecção da aorta descendente. Arq Bras Cardiol. 1998;70(6):389-92. doi:10.1590/S0066-782X1998000600002.

22. Marcolino E. Domingo Braile: surgical innovations. Pesquisa FAPESP. 2010 edição 176 [cited 2020 nov 3]. Available from: https://revistapesquisa. fapesp.br/en/domingo-braile-surgical-innovation/

23. Braile DM, de Godoy MF. História da cirurgia cardíaca no mundo. Rev Bras Cir Cardiovasc;27(1):125-36. doi:10.5935/1678-9741.20120019.

24. Prates PR. Pequena história da cirurgia cardíaca: e tudo aconteceu diante de nossos olhos. Rev Bras Cir Cardiovasc. 1999;14(3):177-84.

25. Costa IA. História da cirurgia cardíaca brasileira. Rev Bras Cir Cardiovasc;13(1):1-7. doi:10.1590/S0102-76381998000100002.

26. Braile DM, Gomes WJ. Evolution of cardiovascular surgery: the Brazilian saga. A history of work, pioneering experience and success. Arq Bras Cardiol. 2010;94(2):141-2, 151-2, 143-4. doi:10.1590/s0066$782 \times 2010000200002$.

27. Camargo JJ. O médico que somos, é o melhor que podemos ser? An Acad Nac Med. 2019;19(2):73-8.

28. Basilio de Oliveira CA. Origem e evolução do pensamento humano: a importância das academias. An Acad Nac Med.2019;19(especial):13-17.

29. Gusmão S. Evolução e Importância. Rev Med Minas Gerais 2003;13(2):146-53. 